\title{
Influencing Characteristics for Housing Product in Jakarta Metropolitan Area
}

\author{
Raden Aswin Rahadi', Sudarso Kaderi Wiryono', \\ Deddy Priatmodjo Koesrindartoto ${ }^{1}$, Indra Budiman Syamwil ${ }^{2}$ \\ 1School of Business \& Management, \\ 2School of Architecture, Planning, and Policy Development, \\ Bandung Institute of Technology, Jl. Ganesha No. 10, Bandung 40132, Indonesia \\ aswin.rahadi@sbm-itb.ac.id
}

\begin{abstract}
This research paper will try to analyze the relationship between influencing characteristics for housing product price in Jakarta Metropolitan Region. The aforementioned characteristics are viewed from the property practitioner perception. To find the answer for this research paper questions, seven property practitioners were interviewed to test the initial hypotheses. The findings suggest that brands, facilities, developer reputations, pricing policies, reinvestment values, and speculative behavior play significant parts as internal and external attributes for housing price in Jakarta Metropolitan Region.
\end{abstract}

Keywords: Real estate; property; consumer preferences; property practitioner perception

eISSN 2514-751X @ 2018. The Authors. Published for AMER ABRA cE-Bs by e-International Publishing House, Ltd., UK. This is an open-access article under the CC BY-NC-ND license (http://creativecommons.org/licenses/bync-nd/4.0/). Peer-review under responsibility of AMER (Association of Malaysian Environment-Behaviour Researchers), ABRA (Association of Behavioural Researchers on Asians) and cE-Bs (Centre for EnvironmentBehaviour Studies), Faculty of Architecture, Planning \& Surveying, Universiti Teknologi MARA, Malaysia.

DOI: https://doi.org/10.21834/aje-bs.v3i9.298 


\subsection{Introduction}

According to Weimer in 1996, property resources have several important characteristics that differentiate them from other commercial products. The characteristics include the product long life span, large economic units, unique market characteristics, heavy government influences, and most importantly, their fixed location.

Focusing on price settlement, when perceiving from property consumer perspective, several key aspects were viewed based on the current given and artificial condition. After that, the process of decision making will take place before the consumer accepts the price.

Property practitioners in the other hand, usually rely on their experience when selling their housing products. Assumptions were made to determine what given factors influencing their product price, and how to create additional artificial factors to boost the housing product price.

Due to this complication, it is always difficult to measure the right value for a housing product. The difficulties happened due to the market heterogeneity, and the fact that the large amount of transactions occurring does not represent market values in an imperfect property market (Aluko, 2007). Different perception between property practitioner and housing consumers is also making the measurement process difficult. Previous research results indicate that property valuers skills and abilities mostly influence the current housing product price in the market (Daly et al., 2003 and Aluko, 2007).

This study will try to determine the attributes influencing housing products price in Jakarta Metropolitan Area. We interviewed property practitioners to understand more about those aforementioned characteristics. The author's previous hypotheses (Rahadi et al., 2012) will be adopted as a base for research questions.

\subsection{Literature Review}

Previously, researchers have conducted several studies to analyze the behavior of housing consumers when they purchase a residential product.

According to Weimer in 1966, research on property consumer preferences can be categorized in two main factors: dwellers and environment characteristics. Dweller's characteristics can be divided into dwellers demographics and social economy while environment characteristics can be divided into neighborhood environment and dwelling.

Study on dwellers characteristics can be found in the research made by Blakely and Snyder (1998); Daly et al. (2003), Shafiei et al. (2010), Zanis and Jusan (2010), and Hapsariniaty et al. (2013). Study on neighborhood characteristics can be found in the research made by Eves (2006); Aluko (2007); Kopits et al. (2007), and Hoshino (2008).

Study in the property developer perception can be classified in two main categories: perception of valuers and on housing product. Housing product perception premise begins with the assumption that residential products are considered as commodities. This perspective supported by studies by the Real Estate Developer Association of Hong Kong (2010) and Chang and Havard (2009). Valuer's perception deals with hidden values of the housing product. These hidden values can be deciphered using valuers past extensive experiences and knowledges. 
Examples of previous research from this point of view include studies from Daly et al. in 2003, Aluko in 2007, Babawale and Oyalowo in 2011 and Knight in 2011. According to Daly et al., (2003) and Aluko (2007), property practitioners often do not include analyzes of consumer preference when determining their housing products price. Mostly, they rely on their past experiences and assumptions.

Lastly, there are several researches that have been conducted to analyze influencing external attributes affecting housing products price. Examples of the studies include:

1. Studies on property cycles by Yusof (2001), Malpezzi and Wachter (2004), Simanungkalit (2009), Reed and Wu (2010), and Pornchokchai (2011).

2. Studies on speculative behaviors by Malpezzi and Wachter (2004) and Pornchokchai (2011).

3. Studies on real estate regulations by Malpezzi (1996) and Eicher (2008).

4. Studies on economic conditions by Hwang and Quigley (2006) and Baker (2008).

5. Study on market demand by Mankiw and Weil (1989).

Findings from these literatures will become the benchmark for hypotheses and research questions to understand influencing attributes for housing product price in Jakarta Metropolitan Area.

\section{0 Methodology}

This research purpose is to analyze influencing attributes for housing product price in Jakarta Metropolitan Area in Indonesia. Ten interview requests letters were sent to several property developers and practitioners in the area. From those ten letters, seven gave positive responses and permits for interviews. The study is taking place in Jakarta Metropolitan Area from November 2012 to January 2013.

Respondents demographic consisted of Serpong, Bogor, Sentul, East Jakarta, West Jakarta, Central Jakarta, South Jakarta, and Bekasi. Respondent's background consisted from senior analyst to managing director of the property development.

We will produce findings by analyzing a collection of interview manuscripts. Word clouds and descriptive approaches were used to present the findings.

\section{Interview Questions}

Questions were asked to the respondents based on the author's dissertation research hypotheses (Rahadi et al., 2012). From the research questions above, respondents were expected to provide their answers for the central questions of this research:

1. Based on respondent's experiences, what are the important attributes influencing their consumer preferences for price of housing products in Jakarta Metropolitan Area?

2. Based on respondent's experiences, what are the important attributes influencing property practitioner's preferences for price of housing products in Jakarta Metropolitan Area? 
3. Based on respondent's experiences, what are the important external attributes influencing the price of housing products in Jakarta Metropolitan Area?

After the respondents gave their initial answers, next a set of sub-questions were presented to the respondents.

Does design, brand, facilities, accessibility, proximity to family, affordability, and livability influence the property practitioner decision when setting up their housing product price?

The answers then combined and analyzed in the next section of this study.

\subsection{Results and Discussion}

For this study, two approaches will be used to present the findings. The first approach is done using cloud analysis. For this approach, the Wordle word cloud application will be used for analysis. Repeated keywords in the interview manuscripts by each of the respondents will be analyzed resulting with larger words production by the application to show the importance of the attributes in the context. For the descriptive approach, frequency analysis will be used to present the significant attributes influencing the property developer preferences, consumer preferences, overall preferences, and overall external factors.

\section{Interview Results: Overall}

In overall, this study is pursuing the answer to the question: What are the most decisive characteristics influencing housing price in Jakarta Metropolitan Area?

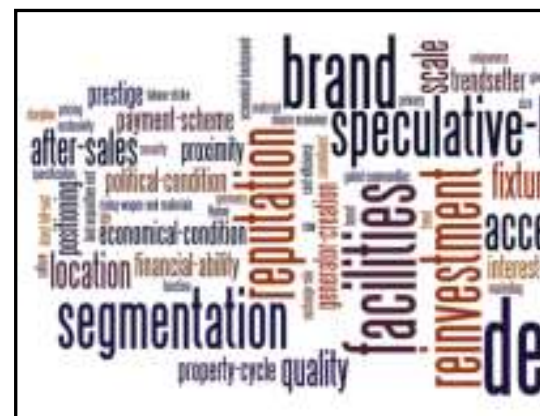

(a)

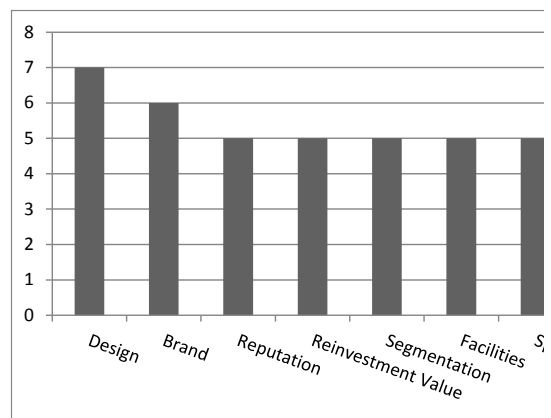

(b)

Figure 1: (a) Interview Results in Wordle Cloud; (b) Frequency Analysis Results (Source: Author's Analysis)

The findings suggested that there are total of 64 (sixty-four) influencing attributes mentioned by the respondents that affect the price of housing products in Jakarta Metropolitan Area.

All of the respondents agreed that designs play a significant part in price definition. Six of the respondents agreed that brands affect pricing decision. Five of the respondents agreed that products reinvestment values, product segmentations, available facilities, property 
developer reputation, and buyer's speculative behaviors help influencing the price of housing products in Jakarta Metropolitan Area. Four of the respondents agree that accessibilities also influence the price of housing products.

\section{Interview Results: Consumer Preferences}

For the next step, the respondents were asked to specify which of the attributes are important perceived from the consumer point of view. The initial hypotheses made by the authors (Rahadi et al., 2012) are used as guidelines to uncover the results.

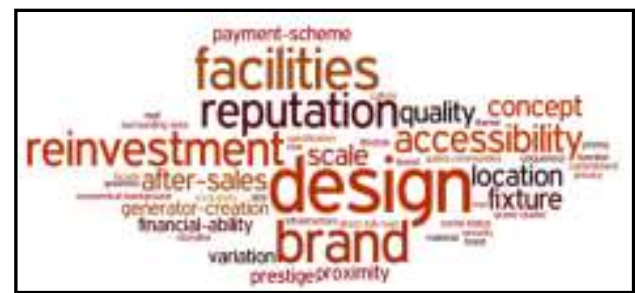

(a)

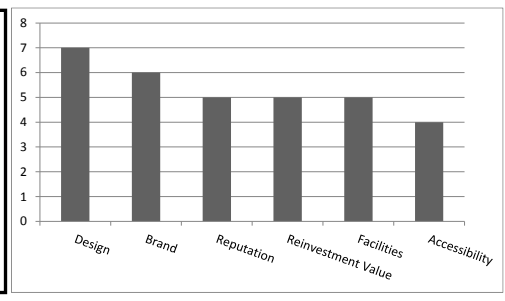

(b)

Figure 2: (a) Interview Results for Customer Preferences in Worlde Cloud; (b) Frequency Analysis results

(Source: Author's Analysis)

Based on the findings, for consumers, there are 46 (forty-six) attributes perceived important to influence housing price in Jakarta Metropolitan Region. Seven of them agree that designs do affect housing price. Six of them agreed that brands do influence housing price. Five of the respondents agree that reputations, facilities, and reinvestment values play an important part in housing price decision. Lastly, four of the respondents agree that accessibilities are vital for housing price decision.

\section{Interview Results: Property Developer Perception}

For the next step, the respondents were asked to specify which of the attributes are important perceived from property practitioners and developers point of view. The initial hypotheses made by the authors (Rahadi et al., 2012) are used as guidelines to uncover the results.
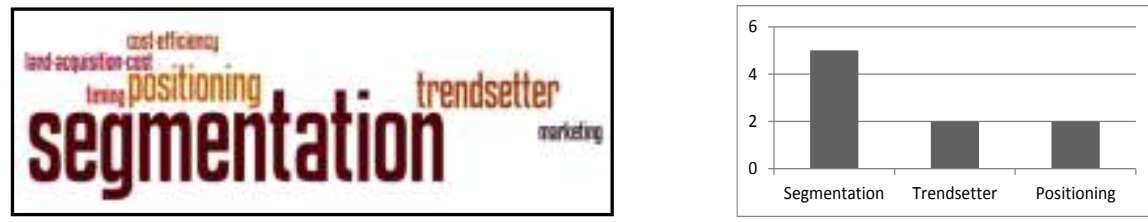

Figure 3: (a) Interview Results for Property Developer and Practitioners Perception in Wordle Cloud;

(b) Frequency Analysis Results

(Source: Author's Analysis) 
There are six attributes influencing housing price, viewed from property developers and practitioner's point of view. Five of the respondents agreed that segmentations are important for housing price decision, while two of the respondents agreed that trendsetters and market positioning can help property developers boost the price of housing products that they sell.

\section{Interview Results: External Factors}

For the final step, the respondents were asked to specify what external influencing attributes that cannot be controlled by either the consumers or the property practitioners but does influence the price of housing products in Jakarta Metropolitan Area. The initial hypotheses made by the authors (Rahadi et al., 2012) are used as guidelines to uncover the results.

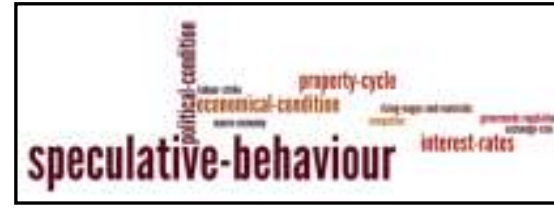

(a)

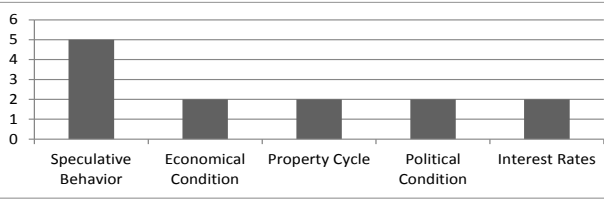

(b)

Figure 4: (a) Interview Results for External Attributes in Wordle Cloud; (b) Frequency Analysis Results (Source: Author's Analysis)

This study result indicates that there are attributes influencing price of housing product that exists and cannot be managed by either the housing consumers or the property developers. We shall call this attributes as external factors.

Five of the respondents strongly agreed that the current speculative behaviors in the market do influence housing price in Jakarta Metropolitan Area. Two of the respondents agree that interest rates for housing mortgage, property cycles, economic conditions, and political climates in Indonesia can also be considered as unmanageable attributes that influence housing price.

\subsection{Conclusion}

Based on the research findings we can see most of the influencing attributes for housing price emerges from their consumer's preferences. Design is the most influencing attribute, followed by facilities, reputation, reinvestment value, and lastly, accessibility. For property developer point of view, segmentation is the most influencing attribute. Lastly, the speculative behavior is the most influencing attribute for the external factor.

Property developer should pay more attention to the consumer's demand in regards with their product design. The current practice for property developers when designing new housing clusters or products are by copying the latest trend of design development in 
countries outside of Indonesia, or following other successful developments made by their competitors. This one-sided preference often led property developer to make guesses on what customers need, resulting with under satisfying housing products.

Brand of property developer is a key factor in price setting. Brands have interconnected if not interchangeable meaning with a reputation that it bears. Property developer will have a better chance to enhance their reputation and brand knowledge if they listen to what their consumers want, and behave professionally by maintaining their product quality with highest standard, delivering their housing products on schedule, and providing their consumers with supportive after sales service. After developing their reputation and brand knowledge, property developers will have a better bargaining power to charge their products at premium compared with their competitors. For start-up property developers, prior to proving the reputation initially they can try and boost their new brand by recruiting proven professionals in their roosters and producing their products with exceptional consultants and contractors.

Facilities provided by property developer are vital when customer plan to purchase a housing product. Facilities are important as it supports their residents day-to-day activities. Most of the property developers in Jakarta Metropolitan Area area attaching their developments with the current facilities of the city such as bus terminals, universities, international airports, or mega malls. Some of the developments, where its remote, produce their own facilities. Examples with BSDCity development in Serpong area who are developing a direct toll road, Alam Sutera development in Serpong area who are developing their own shopping mall, IKEA home center, and Bogor Nirwana Residence in Bogor area who are developing a water park to cater their residents and its surrounding area.

Consumers always prefer to purchase property product that has reinvestment values. For this reason, property developer should always try to look at their products from the consumers point of view, and understand their expectation for their own house in the next 520 years in the future. Property developers should always be aware of what their development position will be in the government plans for the city developments. New toll road development, new terminals, new universities, and other future development are crucial. For this to happen, a regular meeting with the stakeholders should be arranged.

Viewed from property developer perspective, property developer can significantly increase their housing product price and income by carefully determine the segmentation of their housing products and carefully targeting specific housing consumers. Market segmentation process should start from demographic analysis of the intended product target. Starting with product design tinkering, marking the potential ups and downs from the area, mapping the current available and future facilities to be provided and studying the economic condition of the targeted consumers. With the data, property developer can cautiously produce a good product design, place it in the right location, with sound environments and complete facilities. If this works, they can charge a premium price for the housing product in the area.

At last, for the unmanageable speculative behavior for both housing consumers and property developers, it would need government intervention to reduce the influence. Strict law and regulation should be introduced and applied to minimize the housing price fluctuation in Indonesia. 
Finally, all of the findings of this research paper suggested that property developers should look at the consumer preferences to produce a good housing product. A combination of consumer preferences data, property developer past experience and knowledge, and supported with good regulation by the government can be mutually beneficial for all parties involved, which at the end creates a stable housing market in Indonesia.

\section{References}

Aluko, B. T. (2007). Examining valuer's judgement in residential property valuations in residential property valuations in metropolitan Lagos, Nigeria. Journal of Property Management, 98-107.

Babawale, G. K., \& Oyalowo, B. A. (2011). Incorporating Sustainability into Real Estate Valuation: the Perception of Nigerian Valuers. Journal of Sustainable Development, 236-248.

Baker, D. (2008). The housing bubble and the financial crisis. Washington DC: Center for Economic and Policy Research.

Blakely, E. J., \& Snyder, M. G. (1998). Fortress America: gated communities in the United States. Washington, D.C.: Brookings Institution Press.

Chang, N. S., \& Havard, T. M. (2009). Understand How Developers Construct the Pricing of the Residential Property by Process Tracing Protocol. 16th Annual European Real Estate Society Conference in Stockholm, Sweden.

Daly, J., Gronow, S., Jenkins, D., \& Plimmer, F. (2003). Customer behavior in the valuation of residential property: A comparative study in the UK, Ireland and Australia. Journal of Property Management, 295-314.

Eves, C. (2007). Planned residential community developments: do they add value? Journal of Property Management, 164-179.

Hapsariniaty, A. W., Sidi, B. D., \& Nurdini, A. (2013). Comparative Analysis of Choosing to Live in Gated Communities: A case study of Bandung metropolitan area. AiC-QoL 2013 Langkawi Procedia Social and Behavioral Science, 394-403.

Hwang, M., Quigley, J.M. (2006). Economic Fundamentals in Local Housing Markets: Evidence from U.S. Metropolitan Region. Journal of Regional Science, 46(3), 425-453

Hoshino, T. (2008). Estimation and Analysis of Preference Heterogeneity in Residential Choice Behavior. Department of Geography and Environment, London School of Economics, 1-29.

Knight, T. (2011). The perceptions of property developers : approaches to the process of development. Centre for Environment and Society Research, 1-17.

Kopitz, E., McConnell, V., \& Walls, M. (2007). The Trade-off between Private Lots and Public Open Space in Subdivisions at the Urban-Rural Fringe. Resources for the Future, 1-19.

Mankiw. N. G., Weil, D. N. (1989). The Baby Boom, the Baby Bust, and the Housing Market. Regional Science and Urban Economics, 19, 235-258

Malpezzi, S. (1996). Housing Prices, Externalities, and Regulation in U.S. Metropolitan Areas. Journal of Housing Research, 7 (2), 209-241 
Malpezzi, S., Wachter, S. M. (2004), The Role of Speculation in Real Estate Cycles. Zell/Lurie Center Working Papers 401, Wharton School Samuel Zell and Robert Lurie Real Estate Center, University of Pennsylvania.

Pornchokchai, P. (2011). Real Estate Cycles: What Can We Learn? 17th AVA Pre-congress, Thailand 9 July 20-22, 2011, Siem Reap, Cambodia.

Rahadi, R. A., Wiryono, S. K., Koesrindartoto, D. P., Syamwil, I. B. (2012). Relationship between Consumer Preferences and Value Propositions: A Study of Residential Product. AcE-Bs 2012 Bangkok Procedia - Social and Behavioral Sciences, 50, 865-874.

Reed, R., Wu, H., (2010), Understanding property cycles in a residential market, Property Management, 28 (1), 33 -46 .

Shafiei, M. W., Foo, F. S., Said, I., \& Omran, A. (2010). Malacca House Buyers' Housing Preferences in Malaysian New Residential Market. ANNALS of Faculty Engineering Hunedoara - International Journal of Engineering, 217226.

Simanungkalit, P. (2009). Property Investment Strategy in the Global Crisis. Tjiptono Darmadji Network "Seminar Investment In Property", April 14, 2009, Le Meridien Hotel, Jakarta.

Weimer, A. M. (1966). Real Estate Decisions are Different. Harvard Business Review, 105-112.

Yusof, A. (2001). Economy and Commercial Construction Cycle in Malaysia, PRRES Conference 2001, January 2124, 2001. Adelaide, the Pacific Rim Real Estate Society (PRRES).

Zinas, B. Z., Jusan, M. M. (2010). Choice Behaviour of Housing Attributes: Theory and Measurement, Asian Journal of Environment-Behaviour Studies, 1(2), 1-18. 